\title{
TEN NEW RECORDS OF MARINE FISHES FOR SÃO TOMÉ, WEST AFRICA
}

\author{
Nuno VASCO-RODRIGUES ${ }^{1,2^{*}}$, Jorge FONTES ${ }^{3,4}$, and Áthila ANDRADE BERTONCINI ${ }^{5,6}$ \\ ${ }^{1}$ MARE - Marine and Environmental Sciences Centre, ESTM, Polytechnic Institute of Leiria, Peniche, Portugal \\ ${ }^{2}$ Flying Sharks, Lisboa, Portugal \\ ${ }^{3}$ MARE - Marine and Environmental Science Center, University of the Azores, Horta, Azores, Portugal \\ ${ }^{4} I M A R$ - Center of the University of the Azores, Department of Oceanography and Fisheries Horta, Azores, Portugal \\ ${ }^{5}$ Programa de Pós-Graduação em Ciências Biológicas (Biodiversidade Neotropical), UNIRIO - Universidade \\ Federal do Estado do Rio de Janeiro, Rio de Janeiro, RJ, Brazil \\ ${ }^{6}$ Instituto Meros do Brasil, Curitiba, PR, Brazil
}

Vasco-Rodrigues N., Fontes J., Bertoncini Á.A. 2016. Ten new records of marine fishes for São Tomé, West Africa. Acta Ichthyol. Piscat. 46 (2): 123-129.

\begin{abstract}
Three chondrichthyes: Rhincodon typus Smith, 1828; Mobula tarapacana (Philippi, 1892); and Mobula thurstoni (Lloyd, 1908), and seven teleosts: Beryx decadactylus Cuvier, 1829; Peristedion cf. cataphractum (Linnaeus, 1758); Coryphaena hippurus Linnaeus, 1758; Liopropoma emanueli Wirtz et Schliewen, 2012; Chromis cadenati Whitley, 1951; Chromis limbata (Valenciennes, 1833); and Makaira nigricans Lacepède, 1802 were recorded for the first time for São Tomé. These records were based on fishes landed in local markets, captured, or observed while SCUBA diving and from BRUV surveys.
\end{abstract}

Keywords: first record, São Tomé, Tropical Eastern Atlantic, elasmobranchs, teleosts

The Democratic Republic of São Tomé and Príncipe is a group of two islands in the Gulf of Guinea (western Africa), lying between the Equator line and $1^{\circ} 42 \mathrm{~N}$ (Fig. 1). São Tomé, the largest island, is located about 250 $\mathrm{km}$ west off mainland Africa. Despite being considered a marine biodiversity hotspot (Roberts et al. 2002), the marine fauna of the Gulf of Guinea is understudied when compared to other regions at similar latitudes.

Since the work of the Portuguese scientist Osório, late in the 19th century, very few studies have addressed the costal biodiversity from São Tomé e Príncipe (STP). Currently there are 234 reported marine fish species for the region (Afonso et al. 1999, Wirtz et al. 2007).

During an expedition to São Tomé Island, in November 2015, aiming to document costal ichthyofaunal diversity, the authors of the presently reported study recorded unreported marine fish species for the region. These new records result from approximately ten hours of sampling in local markets and fisheries landing sites in São Tomé island, 52 hours of SCUBA diving (46 hours in Rolas Islet (an islet south of São Tomé), five hours in Lagoa Azul, in São Tomé island, and one hour in Santana islet) and 7 hours surveys with a Baited Remote Underwater Video
(BRUV) system. Recent reports by local collaborators were also included whenever they could be verified and supported by photographic evidence. Families are listed according to Nelson et al. (2016) and mobulas identification was based on Notarbartolo-di-Sciara (1987).

\section{Family RHINCODONTIDAE \\ Genus Rhincodon Smith, 1829 \\ Rhincodon typus Smith, 1828}

A single individual of circa eight meters TL was observed late November 2015 (Fig. 2A), while scuba diving at Santana islet $\left(0^{\circ} 14^{\prime} 30.01^{\prime \prime} \mathrm{N}, 6^{\circ} 45^{\prime} 26.67^{\prime \prime} \mathrm{E}\right)$. According to the dive guide, J. Câmara, the whale shark swum unwary four times from the bay to the islet, at 5-8 $\mathrm{m}$ depth.

The world's largest fish, feeds on plankton and can grow up to at least $12 \mathrm{~m}$, perhaps up to $18 \mathrm{~m}$ (Colman 1997, Eckert and Stuart 2001). Whale sharks are circumglobal in all tropical and warm temperate seas, oceanic and coastal except the Mediterranean (Compagno 2001), but to date, this species had not been reported for STP. Seasonal feeding aggregations of larger numbers (tens, to low hundreds) are recorded from many areas in the African 


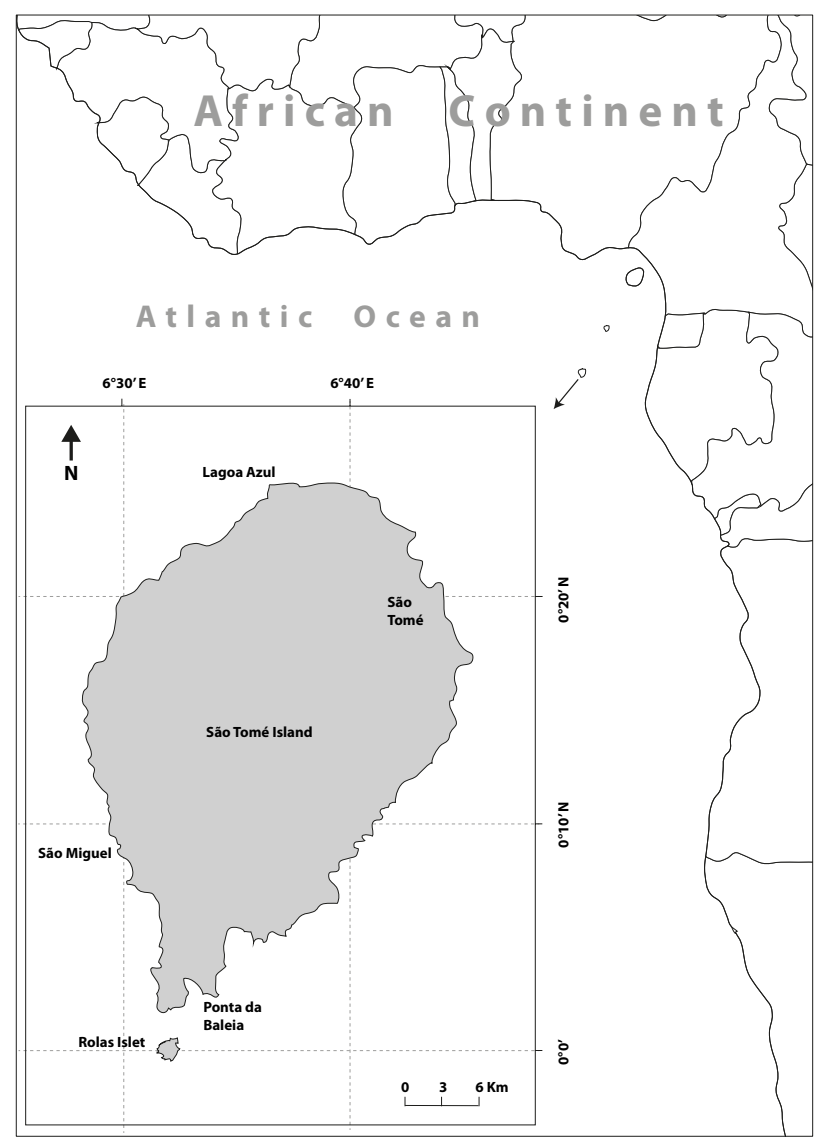

Fig. 1. Geographic location of São Tomé, Africa

continent such as Tanzania, Mozambique, South Africa, Somalia (Norman 2005), but so far, none for the West African coast. The whale shark is listed as Endangered (EN) by IUCN (Pierce and Norman 2016).

Family MOBULIDAE

Genus Mobula Rafinesque, 1810

\section{Mobula tarapacana (Philippi, 1892)}

One specimen with approximately $180 \mathrm{~cm}$ wingspan was seen and photographed in a restaurant (Fig. 2B), in São Tomé city. Two other individuals were recorded $\mathrm{NW}$ off Rolas Islet, free swimming in the water column at $30 \mathrm{~m}$ deep, in May 2015. The animals were observed over the top of an underwater cliff, which raises from more than 300 to $80 \mathrm{~m}$ of depth. According to the dive instructor Relmison Ferreira (RF), the animals, with approximately $2 \mathrm{~m}$ wingspan, approached the diver from the bottom and circled him for more than 15 minutes. One month later, $\mathrm{RF}$ recorded another individual flapping its fins at the surface during a fishing trip to the same area. It remained at the surface for a few minutes before diving. The distribution of this species is circumglobal in temperate and tropical oceans with reports of its presence scattered across the Indian, Pacific and Atlantic Oceans (Compagno and Last 1999). In the North Atlantic, M. tarapacana is known to perform large scale seasonal migrations from their northern distribution limit, the Azores archipelago (Sobral and Afonso 2014), to the region of Cape Verde islands in West Africa (Thorrold et al. 2014), suggesting high degree of population connectivity, at least in the northeast Atlantic, possibly including the Gulf of Guinea. Mobula tarapacana is listed as Vulnerable (VU) by IUCN (Pardo et al. 2016).

\section{Mobula thurstoni (Lloyd, 1908)}

One individual with approximately $140 \mathrm{~cm}$ wingspan was photographed in a restaurant (Fig. 2C), in São Tomé city, in February 2016. It was an immature male and was caught by a local fishermen off São Tomé city. This species is pelagic but more common near the coast (McEachran and Notarbartolo di Sciara 1995). Its geographic distribution is probably circumglobal in all temperate and tropical seas,
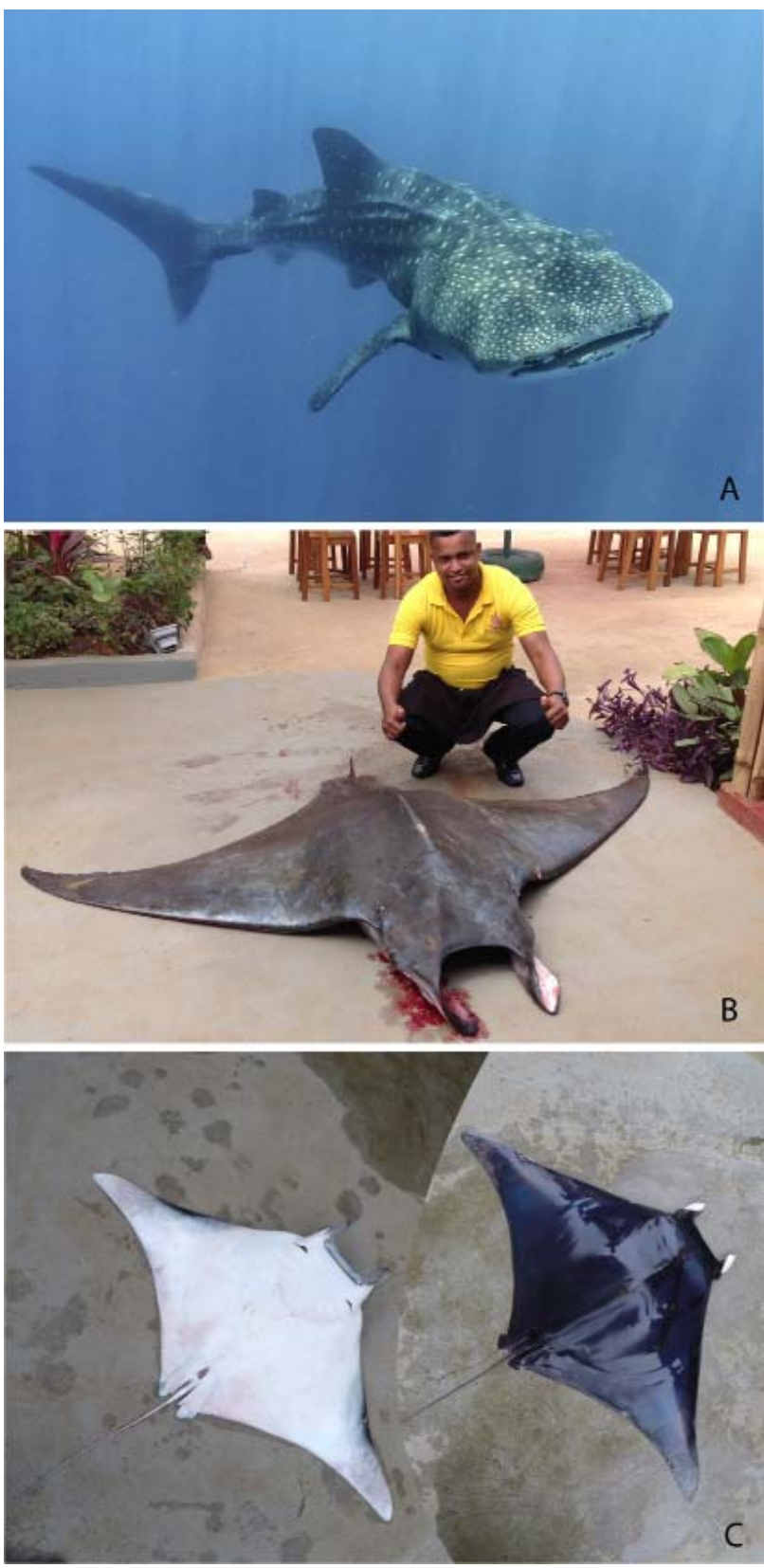

Fig. 2. Presently reported fish from São Tomé, Africa: Rhyncodon typus (A), Mobula tarapacana (B), M. thurstoni (C); Photo credits: Paulo Pichel (A), Hugo Lagos (B), and João Câmara (C) 
but not completely defined. In the eastern Atlantic it has been reported for Côte d'Ivoire and Senegal (Clark et al. 2006) but not for STP. It is listed as Near Threatened (NT) by IUCN (Clark et al. 2006).

\section{Family BERYCIDAE}

Genus Beryx Cuvier, 1829

\section{Beryx decadactylus Cuvier, 1829}

A single specimen of approximately $40 \mathrm{~cm}$ TL was documented in São Tomé market (Fig. 3A). According to local fishermen and fishmongers all fish sold in the market are fished locally and no fish imports are known. Despite its worldwide distribution (Maul 1990), this species had not been recorded in São Tomé before. Being a benthopelagic fish from the bottom of the upper slope, between 200 and $900 \mathrm{~m}$ depths (Maul 1990), it is not surprising that it has not been reported before since most fisheries in São Tomé are costal or pelagic and previous publications focused only on coastal fish (Afonso et al.1999, Wirtz et al. 2007) and possibly did not consider Beryx spp. even though it may had been previously observed.

\section{Family PERISTEDIIDAE}

Genus Peristedion Lacepède, 1801

Peristedion cf. cataphractum (Linnaeus, 1758)

While analysing the stomach content of the aforementioned $B$. decadactylus, one individual with approximately $8 \mathrm{~cm}$ TL was found (Fig. 3B). This species is known to occur in the eastern Atlantic, from the British Isles to Angola, including the Mediterranean, in depths between 50 and $600 \mathrm{~m}$ (Miller and Richards 1990). Given the likely fishing gear (hand lines) negative selectivity of this small fish, the depth limits of local artisanal fishing and the fact that this is not a commercial species in São Tomé, it is not surprising that it had never been reported for São Tomé before.

\section{Family CORYPHAENIDAE}

Genus Coryphaena Linnaeus, 1758

\section{Coryphaena hippurus Linnaeus, 1758}

Three specimens were recorded and one was photographed (Fig. 3C) and sampled during an artisanal fishing landing in Rolas Islet. Wirtz et al. (2007) recorded Coryphaena equiselis Linnaeus, 1758 for São Tomé but not C. hippurus. Considering dolphinfish is a circumtropical ocean pelagic species and widely important as a commercial fish (Oxenford 1999) it is somehow surprising that it had not been recorded for São Tomé in previous studies. The low sampling effort for this region, associated with possible seasonal fluctuations in abundance of this species might explain the inexistence of previous reports.

Family SERRANIDAE

$$
\text { Genus Liopropoma Gill, } 1861
$$

\section{Liopropoma emanueli Wirtz et Schliewen, 2012}

At least six individuals were observed and one was photographed (Fig. 3D) while scuba diving (five of them in São Miguel $\left(0^{\circ} 07^{\prime} 49.76^{\prime \prime} \mathrm{N}, 6^{\circ} 28^{\prime} 41.57^{\prime \prime} \mathrm{E}\right)$ and one in Ponta Baleia, $\left(0^{\circ} 01^{\prime} 59.79^{\prime \prime} \mathrm{N}, 6^{\circ} 33^{\prime} 17.58^{\prime \prime} \mathrm{E}\right)$ São Tomé island, at depths between 32 and $47 \mathrm{~m}$. The animals were observed swimming close to the sea bottom in rocky boulders habitat (diameters between 30 and $150 \mathrm{~cm}$ ) with high density of gorgonians. In the same habitat, Coris atlantica Günter, 1862, Paranthias furcifer (Valenciennes, 1828), Heteropriacanthus cruentatus (Lacepède, 1801), and Gorogobius stevcici Kavačić et Schliewen 2008, were often observed. This species was recently described from Cape Verde Islands (Wirtz and Schliewen 2012) and is also known from Senegal (Wirtz 2014). Its presence in São Tomé, so far, appears to confirm Wirtz et al. (2007) observations of "an undescribed species of the genus Liopropoma".

\section{Family POMACENTRIDAE \\ Genus Chromis Cuvier, 1814 \\ Chromis cadenati Whitley, 1951}

While exploring deep water rocky reefs between 90 and $100 \mathrm{~m}$ NW Rolas Island using a BRUV we documented a school with more than 15 Chromis cadenati, with approximately $15 \mathrm{~cm}$ TL (Fig. 3E). This damselfish was previously reported for Senegal, Guinea, Liberia and Ghana from depths between 20 and $60 \mathrm{~m}$ (Wirtz 2012, Rocha and Myers 2015). This new record expands not only its geographic distribution, but it is also the deepest observation of any damselfish, which are typically common on coral and rocky reefs, but also in other shallow-water habitats including sand and rubble patches, silty embayments, harbours, and seagrass beds (Allen 1991).

\section{Chromis limbata (Valenciennes, 1833)}

Various individuals were recorded in two dives in São Miguel $\left(0^{\circ} 07^{\prime} 49.76^{\prime \prime} \mathrm{N}, 6^{\circ} 28^{\prime} 41.57^{\prime \prime} \mathrm{E}\right)$ at depths between 32 and $40 \mathrm{~m}$. Observed individuals ranged in size from 3 to 12 cm TL (Fig. 3F) and all were swimming close to the bottom in the same type of habitat as described for Liopropoma emanueli. Known as the Azores Chromis, C. limbata was once believed to be restricted to the Macaronesian Islands (Azores, Madeira, and Canaries) and the western coast of Africa (between Senegal and Congo) (Wood 1977, Edwards 1986, Rocha et al. 2008). It has, however, been reported for areas far from its originally known occurrence, such as South Brazil (Leite et al. 2009) and as far as Luanda (Angola) (Patrícia De Brito, personal communication) (Fig. 3G), which is its new southernmost record for the eastern Atlantic.

Despite the currently known wide (and possible spreading) distribution, this represents the first record of this species for an African island. In either case, the mechanisms that have allowed these wide range expansions remain obscure. Given the scarcity of studies in this region, we have to consider both the possibility that this population derived from a recent colonization, potentially originating from the Macaronesia, or an ancient relict population.

\section{Family ISTIOPHORIDAE}

Genus Makaira Lacepède, 1802

\section{Makaira nigricans Lacepède, 1802}

One specimen of blue marlin was recorded in this study, while an artisanal fisherman was landing his catch in Rolas Islet (Fig. 3H). This species occurs in tropical and 

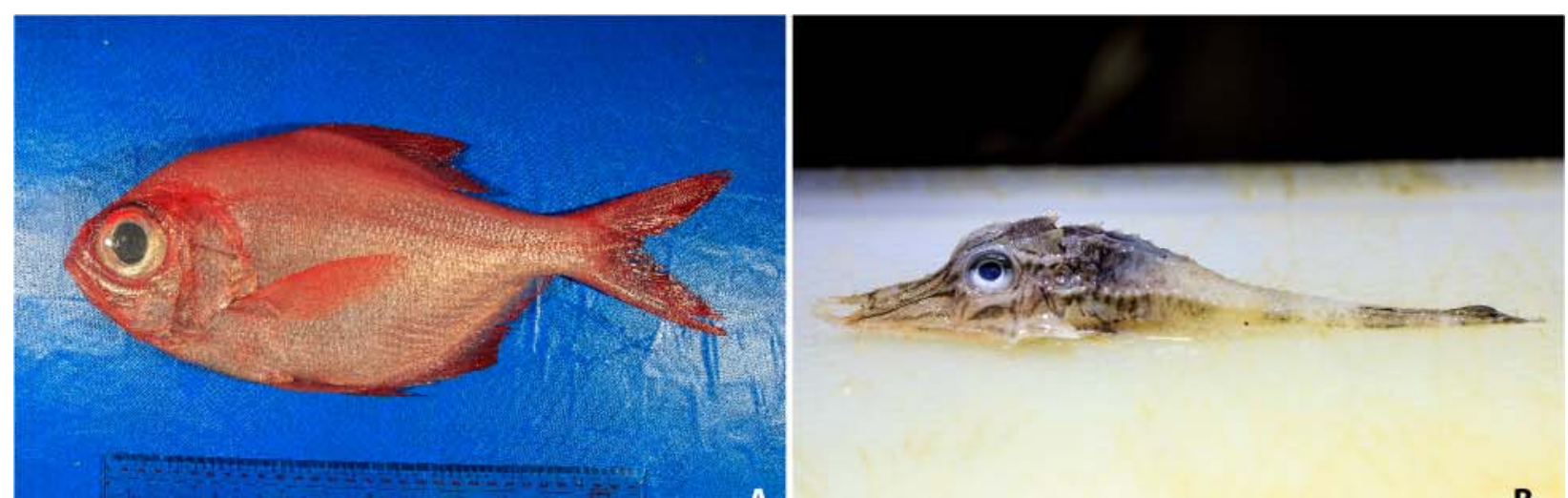

A
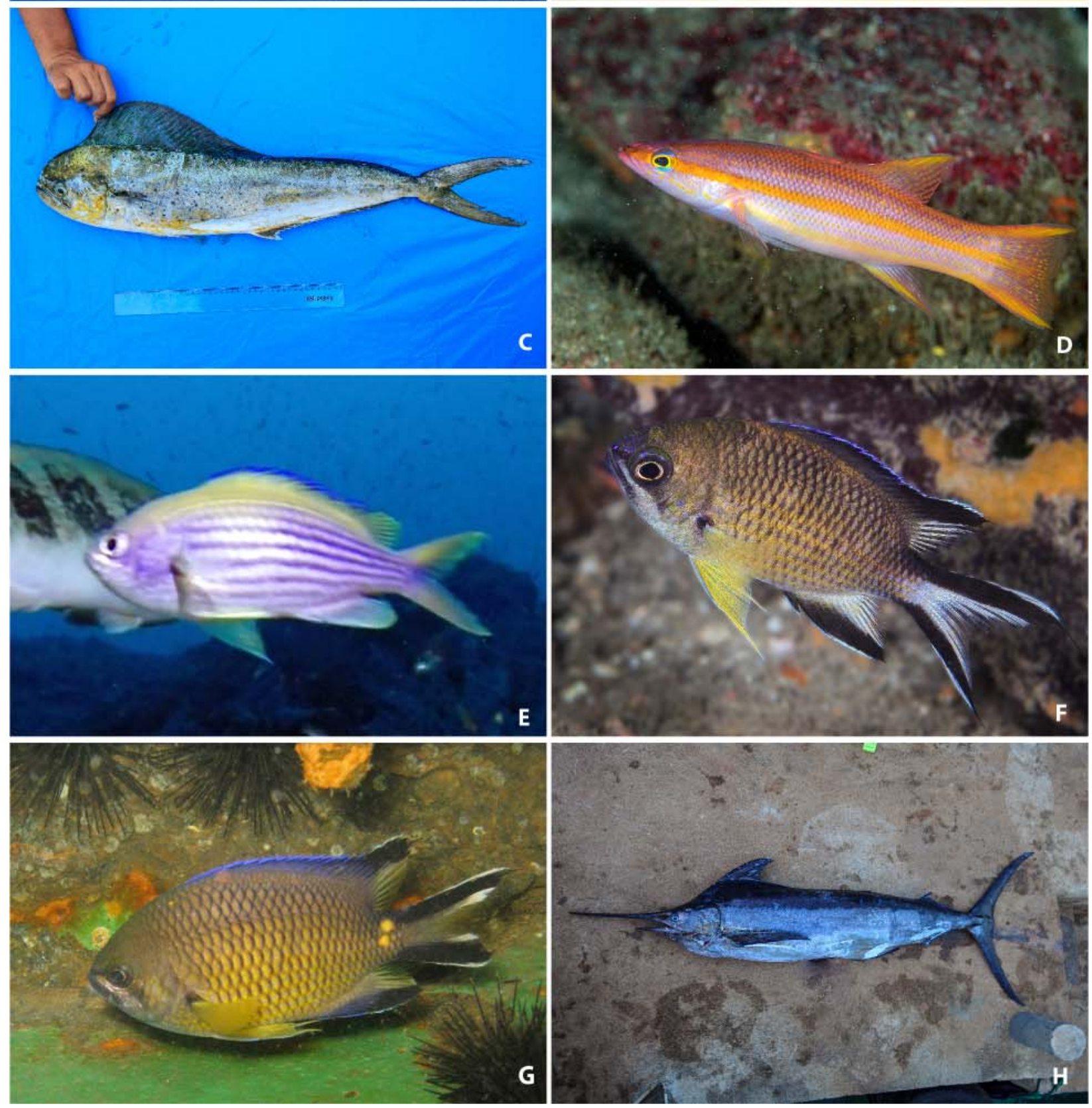

Fig. 3. Presently reported fish from São Tomé, Africa: Beryx decadactylus (A), Peristedion cf. cataphractum (B), Coryphaena hippurus (C), Liopropoma emanueli (D), Chromis cadenati (E), Chromis limbata from São Tomé (F), C. limbata from Angola (G), Makaira nigricans (H); Photo credits: Áthila Andrade Bertoncini (A, B, C, D, F, H), JF (E); Carlos Araújo (G) 
temperate Atlantic waters (Nakamura 1985). Previously unreported, the presence of this species in São Tomé may be explained by the same reasons as for Coryphaena hippurus, i.e., a low sampling effort, although it is occasionally seen in local fish markets around the island.

These new records for São Tomé are not surprising given the tropical/sub-tropical affinities of most species. Despite wider latitudinal distributions of Beryx decadactylus and Peristedion cf. cataphractum - both also occur in temperate and cold high latitude waters (Maul 1990, Wheeler 1992) - these two species are not considered coastal, and have not been addressed in previous studies.

Our report of Rhincodon typus, Mobula tarapacana, and Mobula thurstoni, all pelagic and migratory species, further stresses the absence/rarity of elasmobranchs in São Tomé, possibly due overexploitation and consequent population decline. Photographic records from 2015 and 2016 and comments from local fishermen and restaurant owners are evidence that devil rays are marketed in STP. In some Asian markets (e.g., Indonesia), its gill rakers can reach a high value and the flesh is used for human consumption (Clark et al. 2006). As far as we were informed, in São Tomé there is not a market for gill rakers, either local or export but, according to local restaurant owners and fishermen, devil rays are locally caught occasionally and sold commercially for food.

In approximately 52 hours of underwater observations, between 1 and $47 \mathrm{~m}$ depth, and besides the Whale shark, we only recorded one elasmobranch, Myliobatis sp., in a deep reef, which swam away when approached. Even in our visits to local markets and fisheries landing sites no elasmobranchs were observed. One of the authors (NV-R) reported that Ginglymostoma cirratum (Bonnaterre, 1788) was a common shark in shallow areas in 2005.

During our study, we also reported the presence of Uropterygius wheeleri Blache, 1967. One individual was observed on a rocky vertical wall, at approximately $6 \mathrm{~m}$ depth, during a night dive, in Baía Chinha $\left(0^{\circ} 00^{\prime} 17.54^{\prime \prime} \mathrm{S}, 6^{\circ} 31^{\prime} 42.47^{\prime \prime} \mathrm{E}\right)$, Rolas Islet. Since the animal was inside a crevice, except for the head (Fig. 4), total length estimation was not possible. This species had been reported by Osório $(1891,1898)$ but the most recent papers dedicated to updates on fish species for São Tomé, namely Afonso et al. (1999) and Wirtz et al. (2007) did not give $U$. wheeleri as a valid species. This report confirms its presence in São Tomé.

Although STP has a rich ichthyofauna (yet understudied), symptoms of overfishing are clear, such as:

- The lack of top predators, mainly sharks and large groupers, with only a few large Lutjanids occasionally observed-Lutjanus dentatus (Duméril, 1861) and Lutjanus agennes Bleeker, 1863;

- The presence of fishing net debris in the reefs;

- Signs of gear impact on the sea floor (e.g. large broken gorgonians were frequently seen);

- (Prevalence of small size fishes, namely herbivores, such as parrotfishes (Scarus and Sparisoma), in the local fish markets.

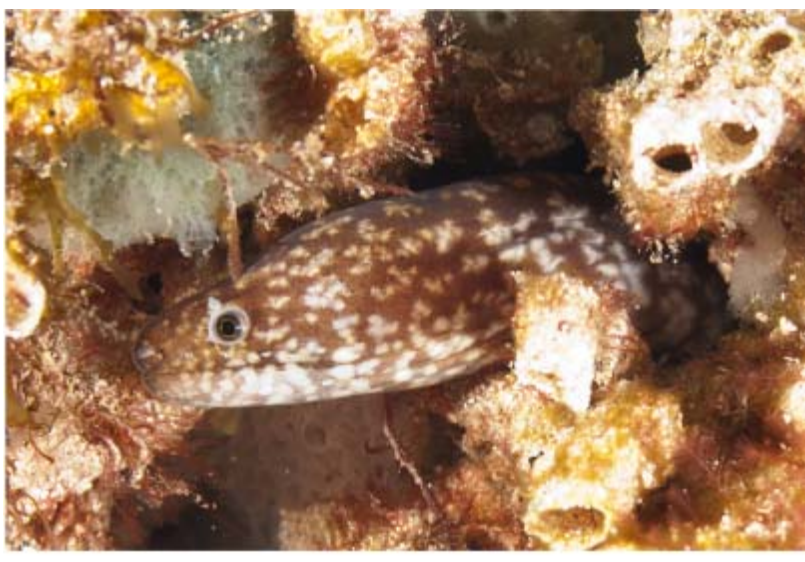

Fig. 4. Uropterygius wheeleri; Photo credit: Nuno Vasco-Rodrigues

This scenario results from local small scale artisanal fisheries alone, since large scale fisheries (namely trawling) or use of explosives was not reported for the area. In light of these facts, conservation efforts in STP are deemed urgent. It is relevant to note that the local population is evenly dependent on fish protein. Out of 30 meals present to the authors at the Rolas village (only one native food serving establishment exists) only three where non fish protein. Conservation efforts such the establishment of marine protected areas would probably benefit from the introduction of alternative affordable protein source in order to preserve the richness and uniqueness of the local marine fauna and the sustainability of artisanal fishing.

With these new records, the number of known valid species for São Tomé and Príncipe increases to a total of 245. A more intense sampling effort including (1) regular surveys to local markets and fisheries landing sites in São Tomé, but also in Príncipe island, (2) sampling of deeper water habitats, usually inaccessible by recreational scuba diving, and using techniques that allow effective sampling, will potentially increase the number of species for this rich and important area of the tropical east Atlantic.

\section{ACKNOWLEDGEMENTS}

The authors would like to thank Relmison (Dodó) Ferreira for the hospitality, friendship, and support, and Costa Norte for logistics with dives and accommodation in Ilhéu das Rolas. Also Patrícia de Brito for the contacts provided and useful information regarding diving in Angola. João Câmara and Lúcia Dias for the hospitality, friendship, help and accommodation in São Tomé. Paulo Pichel, Hugo Lagos and Carlos Araújo for the pictures of $R$. typus, M. tarapacana and C. limbata respectively. Ana Filipa Sobral and Alberto Brito for the help given in the identification of $M$. thurstoni and $U$. wheeleri respectively. Ronald Fricke for the help with identification of various specimens and Peter Wirtz for the help with identification of various specimens, valuable comments and suggestions to the manuscript and enthusiastic support. NV-R benefited from an European Union of Aquarium Curators grant, JF was funded by MARE, ÁAB benefits from a scholarship PNPD/CAPES. 


\section{REFERENCES}

Afonso P., Porteiro F.M., Santos R.S., Barreiros J.P., Worms J., Wirtz P. 1999. Coastal marine fishes of São Tomé island (Gulf of Guinea). Arquipélago: Life and Marine Sciences 17a: 65-92.

Allen G.R. 1991. Damselfishes of the world. Mergus Verlag, Melle, Germany.

Clark T.B., Smith W.D., Bizzarro J.J. 2006. Mobula thurstoni. The IUCN Red List of Threatened Species 2006: e.T60200A12317473. Downloaded on 10 February 2016. DOI: 10.2305/IUCN.UK.2006.RLTS.T60200A12317473.en

Colman J.G. 1997. A review of the biology and ecology of the whale shark. Journal of Fish Biology 51: 12191234.

DOI: $10.1111 / \mathrm{j} .1095-8649.1997 . t b 01138 . x$

Compagno L.J.V. 2001. Sharks of the world. An annotated and illustrated catalogue of shark species known to date. Vol. 2. Bullhead, mackerel and carpet sharks (Heterodontiformes, Lamniformes and Orectolobiformes). FAO Species Catalogue for Fishery Purposes. No. 1, Vol. 2. FAO, Rome.

Compagno L.J.V., Last P. 1999. Mobulidae. In: Capenter K.E., Niem V.H. (eds.) FAO species identification guide for fishery purposes. The living marine resources of the western Central Pacific.Vol. 3. Batoid Fishes, Chimeras and Bony Fishes. Part 1. Elopidae to Linophymidae. FAO, Rome.

Eckert S.A., Stewart B.S. 2001. Telemetry and satellite tracking of whale sharks, Rhincodon typus, in the Sea of Cortez, Mexico, and the north Pacific Ocean. Environmental Biology of Fishes 60: 299-308.

DOI: $10.1023 / \mathrm{A}: 1007674716437$

Edwards A. 1986. A new damselfish, Chromis lubbocki (Teleostei: Pomacentridae) from the Cape Verde Archipelago, with notes on other Eastern Atlantic pomacentrids. Zoologische Mededelingen 60 (12): 181-207.

Leite J.R., Bertoncini Á.A., Bueno L., Daros F., Alves J., Hostim-Silva M. 2009. The occurrence of Azores chromis, Chromis limbata in the south-western Atlantic. Marine Biodiversity Records 2: e145.

DOI: $10.1017 / \mathrm{S} 1755267209990637$

Maul G.E. 1990. Berycidae. P. 626. In: Quero J.C., Hureau J.C., Karrer C., Post A., L. Saldanha (eds.) Check-list of the fishes of the eastern tropical Atlantic (CLOFETA). Vol. 2. JNICT, Lisbon; SEI, Paris; and UNESCO, Paris.

McEachran J.D., Notarbartolo di Sciara G. 1995. Mobulidae. Mantas, diablos. Pp. 759-764. In: Fischer W., Krupp F., Schneider W., Sommer C., Carpenter K.E., Niem V. (eds.) Guia FAO para Identification de Especies para los Fines de la Pesca. Pacifico CentroOriental. 3 Vols. FAO, Rome.

Miller G.C., Richards W.J. 1990. Peristediidae. Pp. 685. In: Quero J.C., Hureau J.C., Karrer C., Post A., Saldanha L. (eds). Check-list of the fishes of the eastern Atlantic (CLOFETA). Vol. 2. JNICT, Lisbon; SEI, Paris; and UNESCO, Paris.
Nakamura I. 1985. FAO species catalogue. Vol. 5. Billfishes of the world. An annotated and illustrated catalogue of marlins, sailfishes, spearfishes and swordfishes known to date. FAO Fisheries Synopsis No. 125 .

Nelson J.S., Grande T., Wilson M.V.H. 2016. Fishes of the world. 5th edn. John Wiley and Sons, Hoboken, NJ, USA.

Norman B. 2005. Rhincodon typus. The IUCN Red List of Threatened Species 2005: e.T19488A8913502. Downloaded on 07 January 2016.

DOI: 10.2305/IUCN.UK.2005.RLTS.T19488A8913502.en

Notarbartolo-di-Sciara G. 1987. A revisionary study of the genus Mobula Rafinesque, 1810 (Chondrichthyes: Mobulidae) with the description of a new species. Zoological Journal of the Linnean Society 91 (1): 1-91.

Osório B. 1891. Estudos ichtyológicos acerca da fauna dos domínios portugueses na África, $3^{\mathrm{a}}$ nota: Peixes marítimos das ilhas de S. Thomé, do Princípe e ilhéo das Rolas. [Ichthyological studies of the fauna of the Portuguese dominions in Africa, 3rd note: marine fish of the islands of St. Thomé and Princípe das Rolas.] Jornal de Sciencias mathematicas, physicas e naturaes. 2a Série 2 (6): 97-139. [In Portuguese.]

Osório B. 1898. Da distribuição geográfica dos peixes e crustáceos colhidos nas possessões portuguesas da África Occidental e existentes no Museu Nacional de Lisboa. [The geographical distribution of fish and shellfish harvested from the Portuguese possessions of Occidental Africa and existing at the National Museum of Lisbon.] Jornal de Sciencias mathematicas, physicas e naturaes. $2^{\text {a }}$ Série 5 (19): 185-207. [In Portuguese.]

Oxenford H.A. 1999. Biology of the dolphinfish (Coryphaena hippurus) in the western central Atlantic: A review. Scientia Marina 63 (3-4): 277-301.

DOI: $10.3989 /$ scimar. 1999.63n3-4303

Pardo S.P., Walls R.H.L., Bigman J.S. 2016. Mobula tarapacana. The IUCN Red List of Threatened Species 2016: e.T60199A3091224.

DOI: 10.2305/IUCN.UK.2006.RLTS.T60199A12309970.en

Pierce S.J., Norman B. 2016. Rhincodon typus. The IUCN Red List of Threatened Species 2016: e.T19488A2365291.

DOI: 10.2305/IUCN.UK.2005.RLTS.T19488A8913502.en

Roberts C.M., McClean C.J., Veron J.E.N., Hawkins J.P., Allen G.R., McAllister D.E., Mittermeier C.G., Schueler F.W., Spalding M., Wells F., Vynne C., Werner T.B. 2002. Marine biodiversity hotspots and conservation priorities for tropical reefs. Science 295: 1280-1284.

DOI: $10.1126 /$ science. 1067728

Rocha L.A., Myers R. 2015. Chromis cadenati. The IUCN Red List of Threatened Species 2015: e.T188352A1862900. Downloaded on 01 February 2016.

DOI: 10.2305/IUCN.UK.2015 4.RLTS.T188352A1862900.en

Rocha L.A., Rocha C.R., Robertson D.R., Bowen B.W. 2008. Comparative phylogeography of Atlantic reef fishes indicates both origin and accumulation of 
diversity in the Caribbean. BMC Evolutionary Biology 8 (157): $1-16$.

DOI: $10.1186 / 1471-2148-8-157$

Sobral A.F., Afonso P. 2014. Occurrence of mobulids in the Azores, central North Atlantic. Journal of the Marine Biological Association of the United Kingdom 94: 1671-1675.

DOI: $10.1017 / \mathrm{S} 0025315414000964$

Thorrold S.R., Afonso P., Fontes J., Braun C.D., Santos R.S., Skomal G.B., Berumen M.L. 2014. Extreme diving behaviour in devil rays links surface waters and the deep ocean. Nature Communications 5 (4274): $1-7$

DOI: $10.1038 /$ ncomms 5274

Wheeler A. 1992. A list of the common and scientific names of fishes of the British Isles. Journal of Fish Biology 41 (Suppl. A): 1-26.

DOI: $10.1111 /$ j.1095-8649.1992.tb05644.x
Wirtz P. 2012. Seven new records of fish from NGor Island, Senegal. Arquipélago, Life and Marine Sciences 29: 77-81.

Wirtz P. 2014. Two new records of fishes from the coast of Senegal (Pisces). Spixiana 37 (1): 151-152.

Wirtz P., Ferreira C.E.L., Floeter S.R., Fricke R., Gasparini J.L., Iwamoto T., Rocha L.A., Sampaio C.L.S., Schliewen U.K. 2007. Coastal fishes of São Tomé and Príncipe islands, Gulf of Guinea (Eastern Atlantic Ocean) — an update. Zootaxa 1523: 1-48.

Wirtz P., Schliewen U.K. 2012. A new species of Liopropoma Gill, 1862 from the Cape Verde Islands, Eastern Atlantic. Spixiana 35: 149-154.

Wood E.M. 1977. A review of damsel fishes (Pisces: Pomacentridae) of the genus Chromis from the central and eastern Atlantic and the Mediterranean. Journal of Fish Biology 10 (4): 331-345.

DOI: $10.1111 / \mathrm{j} .1095-8649.1977 . t b 04067 . x$

Received: 17 February 2016 Accepted: 24 June 2016 Published electronically: 30 June 2016 